Vol.3, No. 3, September 2021, pp. 418-431,doi.org:10.52567/pjsr.v3i3.266

www.pjsr.com.pk

\title{
TEACHING BELIEFS AND PRACTICES OF TEACHER-EDUCATORS TEACHING IN B.ED. HONS. ELEMENTARY AT A PUBLIC SECTOR UNIVERSITY IN GILGIT CITY
}

\author{
Dil Angaiz \\ Assistant Professor, Department of Educational Development \\ Karakoram International University, Gilgit \\ dilangaiz@kiu.edu.pk \\ Shazia Kanwal \\ MPhil Scholar, Department of Educational Development \\ Karakoram International University, Gilgit \\ shazoglt23@gmail.com \\ Salma Jan \\ Visiting Lecturer, Department of Educational Development \\ Karakoram International University, Gilgit \\ salma_jan49@yahoo.com
}

\begin{abstract}
The purpose of this research study was to examine the teaching beliefs and practices of teacher educators teaching in B.Ed. Hons regarding elementary program in a public sector university in Gilgit city. Within qualitative research, case study design was employed to conduct the research study. Ten teacher educators were selected from within a total population of seventeen teacher educators teaching in the B.Ed. Hons. Elementary program was selected through convenient sampling technique. Research tools included descriptive interview questionnaire, and document analysis. Findings of the study revealed that teachers seemed to believe in variety of teaching strategies and emphasized on giving feedback to students along with other formative and summative assessment strategies. Findings indicated effect of teacher preparation programs in changing teachers' beliefs and practices. However, there appears to be inconsistency in teachers' beliefs and practices. Future research should explore the variation between beliefs and practices.

Key Terms: Pedagogical beliefs and practices, Teacher educators, Elementary programs, Public university, Teaching learning

\section{INTRODUCTION}

Recently, teacher education in Pakistan has undergone significant changes due to various reform efforts in response to the National Educational Policy of 2009 funded by USAID Teacher Education Project. As a result of these reforms, the traditional pre-service programs such as Primary Teaching Certificate (PTC), Certificate of Teaching (CT) and Diploma courses in education have been phased out; and new degree programs of a four-year Bachelor of Education (B.Ed.) Honors and a transitional two-year Associate Degree in Education (ADE) have been implemented across the country. The aim of introducing new programs in teacher education is to prepare prospective teachers for more student learning centered environment and activity based teaching in classroom for the students of different backgrounds. Further, new curricula, course guides, instructional material along with assessment procedures have been developed for newly designed degree programs in pre-service teacher education (Abidoudullah, et all., 2013).

The changing context of the pre-service teacher education programs has created a challenging situation in which teacher educators are expected to improve their pedagogical skills and apply studentcentered, interactive teaching and learning approaches. While the alignment of teacher educators'
\end{abstract}


practices with the suggested approaches is of utmost importance, it has not been a focus of systematic study. There is scarcity of systematic studies on the choices teacher educators make and why they make them. The purpose of this study is to fill this gap and also to formulate recommendations for supporting the teacher educators in overcoming such challenges for effective implementation (Munshi, et all., 2015).

Teachers have a pivotal role in successful implementation of curriculum in schools. Teachers' pedagogical beliefs and teaching practices determine the quality of teaching learning process in the classroom. In addition, teacher educators are the ones who play an important role in improving quality education in the country as they are responsible to produce competent and skillful teachers. Teachers need good training and professional knowledge in order to be able to deliver their knowledge more effectively to their students (Dilshad \& Iqbal, 2010).

\section{STATEMENT OF THE PROBLEM}

New programs and reforms not only result in changing curricula but it also requires changes in beliefs and perceptions regarding teaching practices, instructional materials and assessment procedures. This changing context scenario has created challenging situation for teacher educators. Teacher educators are expected to change their teaching strategies and their pedagogical skills to meet the needs of new curriculum. It is vital to explore and align teacher educators' beliefs and practices for effective implementation of new programs. Although numerous studies in Pakistan (Akber \& Akhter 2013; Khan \& Saeed, 2009; \& Thomas, 2013) were conducted on the pedagogical beliefs and practices; however, there are very few researches on this topic in the context of Gilgit-Baltistan. This study will help in exploring beliefs and practices of teacher educators and formulating recommendations for supporting the teacher educators in overcoming challenges for effective implementation of the new programs.

\section{RESEARCH OBJECTIVES}

Specific objectives of this research are:

1. To explore pedagogical beliefs of teacher educators teaching in B.Ed. Hons. Elementary Program in Public Sector University in Gilgit City.

2. To explore pedagogical practices of teacher educators teaching in B.Ed. Hons. Elementary Program.

\section{Research Questions Main Question}

What are the pedagogical beliefs and practices of teacher educators teaching in B.Ed. Hons. Elementary in a public sector university in Gilgit City?

\section{Subsidiary Questions}

1 What are the pedagogical beliefs of teacher educators teaching in B.Ed Hons programs in a Public Sector University?

2 What are the pedagogical practices of teacher educators teaching in B.Ed. Hons. Elementary?

3 Is there any connection between pedagogical beliefs and practices of teacher educators teaching in the B.Ed. Hons. Elementary program?

\section{SIGNIFICANCE OF THE STUDY}

Modern trends in education system have brought forward many new ways for the teachers. The emerging practices in contemporary education system such as four years B. Ed. Hons. Elementary and two years ADE curriculum have massively become contradictory to the traditional ways of teaching such as PTC, CT and diploma courses for the teachers. The recent developments in education system demands student centered approaches towards teaching and learning. This new genre of teaching has unearthed new challenges for the teacher educators who, unexpectedly, are standing in between both systems of teaching. This study will attempt to bring forth the teachers' beliefs and their actual teaching practices in classrooms at a public sector university in Gilgit. The findings of this study will not only help educators and 
Teaching Beliefs and Practices of Teacher-Educators...

practitioners to amend their teaching methods, but will also help policy makers to reform the teacher education programs in this context.

\section{LIMITATIONS OF THE STUDY}

In this research, data collection process remained a challenge due to Covid-19 lockdown. Majority of the respondents were not able to give interviews on scheduled dates. Therefore, data collection tools had to be changed. Focus group discussion and classroom observations could not be managed due to lockdown of university. Interview questions were emailed to participants instead on taking face to face interviews. Researchers have to rely on the documents, learning materials, course outlines, assignments and reflections to understand connection between beliefs and practices. Although documents provided relevant and required data, but they could not replace real classroom observations and discussions. Hence, absence of data from classroom observations and focus group discussions remained limitations of this study.

\section{REVIEW OF LITERATURE}

Teachers have a central role in implementing changes in schools. The success of teaching learning process in school fully depends on beliefs and effective pedagogies that teachers practice. Khader (2012) described the concept of teacher' beliefs as "teachers' beliefs are a set of ideas rooted in the psychological and mental content of the teacher and plays a central role in guiding his/her teaching behavior" (p.74). Numerous studies such as (Farrell \& Bennis, 2013; Guerra \& Wubbena, 2017; Yamashita, 2011) have found that teachers' practices are strongly influenced by their pedagogical beliefs. Pedagogical practices are defined as a set of teaching strategies and methods of instruction that teachers use in the classrooms to interact with their students in order to expand their intellectual and skillful perceptions. According to Feyfant (2011), pedagogical practices are the practices that educators need to be well-aware of in promoting student learning. Teachers' pedagogical practices help students to learn in terms of the approaches that work for them to the best of their abilities. Students become able to develop the potential for deeper learning if pedagogical practices are implemented effectively ( 8 Ways Open Pedagogy Benefits Teachers and Learners, 2018).

Teacher beliefs and practice are considered to be connected and interacting with each other. Researchers have revealed that classroom performance of a teacher is affected by the variety of beliefs which teacher possesses (Gabrys-Barker, 2010). Consequently, teachers' pedagogical knowledge as well as their pedagogical skills contributes substantially to student achievement (Darling-Hammond \& Hudson, 1990). There is a growing body of literature that examined the relationship between teachers' beliefs and their classroom practices. Some researchers have found that the teachers' beliefs play an important role in the classroom practices. These beliefs affect their teaching abilities and decisions they take in class about student learning (Khader, 2012; Li Li \& Steve, 2011; Ng \& Farrell, 2003). For instance, some teachers believe in teaching students by lecturing or direct teaching, Others reflect constructivist views of teaching and learning by using student centered approaches such as co-operative learning and problem based learning. In higher educational institutions particularly the learners are given autonomy by the instructors through the implementation of pedagogical practices in a meaningful and worthwhile manner (Radhika, 2020).

However, some studies such as (Guerra \& Wubbena, 2017; Purnomo, Suryadi \& Darwish, 2017) have shown that despite training and professional development programs, teachers' classroom practices were inconsistent with their beliefs. Borg (2003) and Saydee (2016) concluded that teacher training programs have little influence on teachers' beliefs regarding classroom practices. In this regard, $\mathrm{Li} \mathrm{Li}$ and Steve (2011) stated that discrepancies may be largely caused by contextual factors such as an 'inability to apply the new ideas within the existing parameters of syllabus, examinations, teacher beliefs coming from their personal experience, lack of collaboration opportunities among teachers, and lack of cultural support (Sturko \& Holyoke, 2009). Nevertheless, consistency between individual beliefs and practice seemed constrained by the school and social environment that surrounds the individual teacher's practice context. 


\section{METHODOLOGY}

\section{Context of the Study}

The study was conducted at a public sector University in Gilgit city. The study includes both regular and visiting faculty of the department of Educational Development. The department runs four programs in Teacher Education; Masters of education, B.Ed. Hons Elementary 4-years, B.Ed. Secondary 1.5 years after 16 years' education, and B.Ed. Elementary 2-years after ADE. This study was carried out with faculty teaching at B.Ed Hons. Elementary program.

\section{SAMPLE SELECTION PROCEDURE}

Sampling is a subgroup of a target population that the researcher plans to study for generalizing about the target population. Cohen, Manian and Morrison (2007) refers sample as a smaller number of participant who are part of large population and the researcher requires collecting data from the selected population. For the study, all the faculty teaching at B.Ed Hons. elementary level for spring semester 2020 were identified using classroom time table and scheme of study. However, few participants were busy due to other administrative and managerial tasks assigned to them by higher authorities of university. Therefore, participants for the purpose of this study were selected using convenient sampling techniques. According to Gall, Borg, and Gall (2003), convenient sampling refers to the selection of group of people who are easily found and available to be studied. The researcher requested and approached only those faculty members who met the following criteria:

1. Participants teaching at B.Ed. (Hons.) Elementary level.

2. Participants had at least two prior years of teaching experience in their current educational role.

3. Participants were willing to participate in the study.

4. Participants were easy to access.

All the faculty who met the above criteria were approached personally or via email by the researchers and requested to participate in the study. Almost all approached faculty showed their willingness to take part in research.

\section{Sample}

Out of the total population ( $\mathrm{n}=17)$, educators teaching in the B.Ed. (Hons.) Elementary program in the selected university, the current study selected ten $(n=10)$ educators. There were no broad variations in terms of variables like regular and visiting faculty, gender, academic qualifications and teaching experience. Refer (appendix A) for details about the demographics of participants

\section{DATA COLLECTION TOOLS}

\section{a) Descriptive interview questionnaire}

Individual descriptive interview questionnaires were emailed to each participant. Participants were requested to give detailed answer to each question. The questionnaire was comprised of three sections. Section A was about exploring teachers' beliefs about teaching and learning, section B was about exploring their practices and section $\mathrm{C}$ aimed to know participants' understanding about relationship between beliefs and practices. Participants were allowed to answer the questions in their own time span. The questionnaire sought to answer participants understanding about teaching, learning, what strategies they use to assess teaching and learning, and how they prepare and implement their lessons in class. Questions further explored their perceptions of content knowledge, student teacher relationship and discovered how they plan and utilize resources for teaching and learning. Participants were also informed that they can be contacted telephonically, if needed for elaboration of responses.

\section{Document analysis}

Document analysis was carried out to compare and confirm the descriptive responses with what they actually practice in classrooms. Participants' documentations included course outlines, course folders, lesson plans, reflections and assignments. With prior permission from the participants and Head of the Department, the documents were accessed. These documents were critically observed and analyzed to see 
the connections between participants' beliefs and practices. Through document analysis, researchers tried to find out evidences for the participants' responses and claims. This process helped researcher to validate the connections between beliefs and responses of participants.

\section{Data Collection Procedures}

The primary sources for data collection in the study were descriptive interview questionnaire, and available documentation such as course outlines, lesson plans, and assignments. Merriam (2009) promoted the idea of interviews and observations to support qualitative research. However, as mentioned earlier, observations could not be managed due to COVID 19 lockdown.

In order to formally initiate data collection, approval from university review board was obtained. Afterwards, university faculty teaching at B.Ed $(\mathrm{H})$ Elementary level were approached for their willingness to participate in the study. Faculty were informed about the purpose of research and requested for participation. Meanwhile COVID 19 Pedantic arouses and university was locked down. After consultation with the faculty telephonically, it was decided to contact agreed faculty electronically. Hence, participants were informed about changes in data collection procedure and requested to respond to the interview questionnaire via email or in hard form if available. They were further requested to provide detailed responses so they could not be bothered again and again for inquiring. Luckily, all participants showed their willingness to respond electronically.

Interview questionnaire was sent to all participants via email to respond to the questions. Meanwhile, researcher started to review and analyse documents provided by participants and Head of the Department. Notes were made regarding their teaching, learning and assessment practices. The notes from document analysis were later transcribed into electronic word document. As soon as researchers received the responses from participants, they started analyzing the data. Respondents were contacted via email and telephone to understand the meanings and responses which were ambiguous and not comprehensible for the researchers.

Subsequently, an open coding process was utilized to analyze the data for themes, concepts, and relationships. Researchers emphasized the use of open coding to divide the data into manageable sections and to identify concepts that help to determine themes from the data (Corbin \& Straus, 2008). The data from interviews were analyzed and compared to the documents. At each stage of data collection, an open coding process was used to identify concepts, themes, and relationships. Axial coding was used to connect related concepts or themes. Through open coding the data was organized for correspondence of two categories of similarities and differences. This process helped in identifying patterns and themes based upon number occurrence. Data analysis was completed by formation of themes.

\section{Validity and Reliability}

In qualitative research, validity and reliability of data is very important in order to keep the quality of research high. Numerous researchers like Merriam (2009), Yin (2003), and Zohrabi (2013), have insisted on using multiple sources to ensure validity and reliability of the study. In this study, limited data collection tools were used so, researchers consciously read interviews, observed and understood all available documents and carefully labeled themes to enhance validity of data that lead towards valid findings and conclusions. Moreover, researchers were mindful of personal biases and assumptions. Researchers tried to separate themselves from any personal thoughts and feelings during the process of data collection.

\section{RESULTS AND FINDINGS}

The results and discussion of the study is presented, based on the research questions and major themes identified about teachers' beliefs and perceptions.

\section{Teaching strategies and preference}

This category pertained to participants' use of teaching strategies and reason for using that particular strategy. A number of participants referred use of group work, presentations, cooperative learning, 
followed by classroom discussion as their preferred teaching strategy. Details about the specific teaching strategies used by participants during classroom teaching are presented in appendix B.

All participants mentioned 'group work' and 'presentation' as their preferred strategies to use in teaching and learning process followed by cooperative learning and discussion. Engagements of these strategies were also evident in participants' reflections and documents such as course outlines and assessment plans. Participant 1 stated that, "classroom discussion, individual and group presentations, lecture method are used because these teaching strategies are helpful in developing cooperative learning skills and emotional control in students". Participant 1 further elaborated that, "these are useful approaches and practices, they are necessary to be implemented in the classroom for effective learning to take place". Participant 3 mentioned that, "Various teaching strategies like cooperative learning, role plays and games are useful ways to encourage tasks and learning achievements". Participants' frequent use of classroom discussions, presentations and lecture method were also evident in the course outlines and lesson plans. While elaborating reasons for the use of these strategies, participant 6 stated that "I think teachers should use strategies which ensure students active involvement and engagement with the lesson because active learning can guarantee students learning and achievement". However, students' active involvement and active learning is questionable because majority of participant teachers gave group work and presentations for the purpose of assessment. If presentation is assigned to assess students learning there are less chances of active involvement of each and every student Instead students rely on relatively competent student in their group to prepare and share the presentation. Moreover, strategies like jigsaw, round table discussion, say and switch seemed to be least used by participants. These strategies were not listed or mentioned in any of the document shared by the participant teachers. On the contrary, Participant 2 described that, "I use multiple strategies based on the student's age \& grade level and strength of the class like cooperative method, Jigsaw, round table discussion, say and switch and role play". But use of these strategies were not evident in his course outlines, lesson plan and classroom activities. For participant 7 such strategies are fashionable strategies which do not give a positive output. She said that, I don't believe in fashionable and modern teaching methods much. Even an interactive lecture method can be effective as compared to a discussion method in classroom where students have less knowledge about a course or a concept. So it all depends on the teacher how he/she makes a teaching method more interesting for students by incorporating questions, case studies, pictures, graphs and interactive power point presentations.

Above excerpt shows that participant was clear about usage of effective strategies. Instead of listing number of innovative strategies one should use and implement simple strategies in an innovative manner that can help students understand the topic and achieve learning outcomes. Findings reveal that participants need to understand and explore teaching strategies that can be more useful and effective for their students. Presentations and discussions are widely used by participant teachers. They also need to have in depth understanding of when, why and how to use these strategies to enhance students' learning.

\section{Lesson planning, an undeniable component of teaching and learning}

When participants' beliefs and practices regarding lesson plan was explored, $100 \%$ participants mentioned that they prepare lesson plans and teach according to their plans. Participants' documents revealed that all participants prepare lesson plans before teaching and they teach according to their plans. Almost all aspects of lesson planning seemed to be fulfilled by the participants. Emphasizing the need and importance of lesson planning, participant 4 said that, "effective planning and preparation can identify which teaching activities are to be implemented within a lesson and also help teachers to utilize effective techniques to get optimum satisfaction over student's learning". Another participant described "It is undeniable component of teaching and learning process. Without preparation, a teacher cannot do justice with students. Planning is a road map which gives a clear direction to teachers during class. I don't go to classroom without prior preparation." Participant 1 stated, "Lesson planning is a road map to my daily activities. I always plan my lessons before teaching in the classroom". Similarly, participant 7 was of the view that, "For every class, I plan objectives, content to be taught, teaching method, and ways to evaluate students learning. As I deal with adult learners so, planning prior to teaching is mandatory because 
teachers cannot deceive adult learners". It was evident from teacher beliefs and practices and document analysis that participant teachers understand the need and importance of lesson planning and they make sure that their lesson plans are ready before the lessons. Participants were aware about all the components of lesson planning. Participant 2 confirmed that he prepares a course by determining its learning objectives, developing a syllabus, and making lesson plans. Participants consider lesson plan as a road map towards teaching. They believed that it not only help participants to make their teaching processes smooth but also help students to engage with activities. Participants believe that lesson plans educate and prepare teachers about course material that lead them towards effective teaching. Participant also mentioned that prior preparation and planning boost teachers' confidence. Participant 9 stated that, "teachers must go in the classroom with lesson planning because it helps to provide relevant and excellent information with confidence". "Planning makes me confident in my class and if I am confident, I make sure students have learnt their best" stated participant 4. Undoubtedly, prior preparation boosts confidence of teachers. Teachers become aware about aims and objectives, teaching, learning and assessment activities. Moreover, both students and teacher use class timing effectively and productively, if lesson plans are well prepared and implemented. Although all participants insisted on importance and preparation of lesson planning, nevertheless they need to understand that students expect more from teachers in terms of relevant teaching and learning activities.

\section{Positive and Constructive feedback}

This category refers to feedback that participant teachers give to the students. Almost all participants gave favorable perceptions towards giving feedback to the students. Moreover, they highlighted that feedback should be constructive, meaningful and timely in order to have significant effects. For instance, Participant 10 said that, "we can say that positive or constructive feedback can enhance students learning". Likewise, participant 1 insisted that, "feedback enhances or boost up students' stamina towards learning". In addition, participants also mentioned that feedback is a tool to help students identify their strength and weakness. According to participant 3, through feedback students realize their weaknesses and strengths and improve their strengths. Participant 5 said that, "Feedback is major priority in my teaching. I cannot take second step until I cannot give feedback to my students". Giving feedback to student was apparent in participant assessment plans, assignments they marked and presentations they have taken. However, there were no in-depth and detailed feedbacks. It was also observed and noted that feed-backs on assessed activities especially on assignments are not shared with students. Quantitative marks are assigned instead of providing written feed-backs. Although teachers believe in giving feedback but its proper implementation seems lacking. For instance, Participant 6 emphasized importance of feedback by saying that "Feedback is part and parcel of assessment. No assessment is complete or make any sense without feedback". However, written feed-backs were missing on the assignment she checked. There can be several ways to give feedback to students for example, oral feedback, collective feedback, individual one to one feedback. But, we think written and detailed feedback is more useful for students in terms of improving their learning.

One of the participant classified feedback into constructive and destructive one and highlighted that it is important for teachers to understand both. She said, "Feedback is one of the best tools to know about ones' weaknesses and strengths. But we can't say that feedback enhances students learning. If teachers have not exact idea about concept of constructive and destructive feedback, it will become disastrous for students". It is true that if students are given destructive feedback either oral or written and they are forced to focus only on weaknesses, it can lead to negative consequences. The purpose of feedback is to help students improve their learning so it is important for teachers to learn how to give constructive feedback and understand dos and don'ts of giving feedback. Superficial understanding about giving feedback can harm students instead of healing. 


\section{Influence of teacher preparation programs on teaching, learning and assessment practices of participants}

Describing the influence of teacher preparation programs on teaching, learning and assessment practices, participants highlighted the influence in positive manner. Participant 1 said that "My beliefs regarding the teaching changes over the period of time as I got experiences of teacher education programs, and opportunities to work with various teachers and teacher educators during my career". Similarly, participant 10 elaborated that her teaching has improved as she got experiences, "different professional development programs and teaching experiences has taught me a lot. I learn new things which I implement in class". This change and improvement was also evident in her scheme of work and course outlines. Her teaching and assessment strategies were changed and seemed better in her work. From the analysis of the data, it was evident that majority of participants believe that they learn and acquire new knowledge and skills from professional development programs especially teaching preparation programs. All those teachers who have gone through any teaching preparation program such as B.Ed and M.Ed endorsed that their teaching beliefs and practices improved and changed after they have attended such programs. Those who have not gone through any teacher preparation programs think that they do not need to change their teaching practices. This finding shows the importance of teacher preparation programs and their effect on teaching. Participant 5 was of the view that teacher education programs are very important because it teaches teachers how to teach and help teachers understand how to teach effectively". In general, most of the participants acknowledged teacher preparatory programs and it emerged as the most widely perceived influence on participants' teaching, learning and assessment. Nonetheless, some participants listed more general statements, such as, "I become a better teacher as a result of teacher education programs", "and "I would not be a good teacher if I had not done B.Ed".

\section{Preferred approach of assessment}

Regarding preferred assessment approach, participants were of the view that, assessment is an important tool to know how well students have learned. They described assessment as actual snapshot of students' learning. Majority of participants endorse formative assessment but they also emphasized the importance of summative assessment. For instance, participants 8 mentioned that, "formative and summative assessment both are the need of institutions". Participant 3 insisted that "I prefer formative assessment as teachers know the actual learning of students in classroom situations. Some students cannot perform in the summative examinations as they may have exam phobias. However, I also use summative assessment approach". Participant 7 mentioned that, "assessment help teachers evaluate whether the educational goals and standards are being met or not. According to my point of view, assessment should answer whether teachers teach according to the plan they developed? Did students learn what they need to learn? Are there better ways to enhance student's learning?" Participant 5 and 8 highlighted that assessment help teachers identify and reward specific qualities in students' work and guide teachers and students to improve their learning. Creating and using rubrics, giving assignments, asking questions during the class, presentation and Quizzes are considered as assessment strategies by the participants. Participant 8 stated that, "After their assignment I evaluate it and provide feedback to them". Similarly, participant 1 indicated that, "I like to give feedback to students on daily basis; preferred approach is ongoing assessment, although I prefer formative \& summative too". Participant 10 said, "Every individual is different So planning of assessing all individuals on same patterns is not a wise decision. Therefore, teachers should have command on different types of assessment". Participant teachers came up with number of assessment strategies along with mentioning formative and summative assessment. Some were repetitive and some were rarely mentioned by participants. Refer (appendix C) for the frequency of different assessment types/approaches mentioned by participants that they claim to use for student's assessment.

Findings indicate that majority of participants assess their students by assignments followed by presentations. Document analysis revealed that teachers are bound to assign assignments and take presentation. Assessment plan is usually shared by university administration and teachers are bound to follow the assigned plan for assessment. They can bring innovation and creativity in their assignments 
and presentation, but no creativity was observed in the assignments. Majority of assignments lead towards summative assessment. This finding supports previous findings regarding feedback. Usual practice is assigning marks for assignments rather than feedback. Similar practices are carried out in assessing presentations. Document analysis informed that very few participants give feedback after presentations. Moreover, half of the participants mentioned quizzes and exams as their preferred assessment approach and majority consider it as formative assessment. Yet, quizzes can be summative depending on its nature and construction. Very few participants mentioned self-reflective exercises, concepts maps and rubrics as their assessment strategies. Nonetheless, no evidences were found regarding their usage in class, exam, and presentation or for the purpose of checking of assignments. In general, it seems that participants lack understanding about assessment strategies and their uses. They seemed to be confused about different assessment strategies.

\section{RESULTS AND DISCUSSIONS}

The results and discussion of this study are presented based on the research questions and major thematic areas emerged as a result of analysis. A detailed discussion is carried out concerning the findings of the study in light of the existing literature about teachers' beliefs and practices.

The results revealed that teaching and learning are not two different things. Teaching is an engagement with learning. Research suggests that incorporation of variety of teaching and learning activities in any teaching can significantly boost students' engagement in learning process. Research has shown that if students do not consider a learning activity worthy of their time and effort, they might not engage in a satisfactory way or may even disengage entirely in response (Fredricks, Blumenfeld, \& Paris, 2004). Therefore, it is the responsibility of teachers to make their teaching learning activities engaging and inspiring. This study revealed that teachers believe in using cooperative teaching and learning strategies and document analysis confirmed that teachers try to involve and engage students in classroom activities. However, few teachers seemed concerned about effective utilization of such strategies due to students' poor academic background and classroom participation. In this study, majority of teachers mentioned about cooperative strategies that facilitate learning but they need to understand that cooperative learning is more than just group work. Many studies have shown that when cooperative learning is implemented correctly, it improves information acquisition and retention, higher-level thinking skills, interpersonal and communication skills, and self-confidence (Johnson, Johnson, \& Smith, 1998). According to Wentzel (2009), collaborative learning is a powerful facilitator of engagement in learning activities. When students work effectively with others, their engagement may be amplified.

Moreover, this study revealed lesson planning as an undeniable component for teaching and learning. Research studies (Hurst, 2001; Ko, 2012) focuses on importance of lesson planning and its results on improvement in teaching and learning. Prior preparation and lesson plans not only develop teachers' confidence but it also makes teaching and learning more effective. Lesson planning always remained a major component in teachers' professional development programs. There are a number of formats to follow for lesson planning. It is also essential to take into account students' differing needs, interests and stages of development. It is important to note that lesson plans should be more than a simple paper exercise, whatever written on paper needs to be implemented in classroom. Teachers who went through professional development programs seem to have good understanding of lesson planning. Teacher training programs enable teachers to spend more time on lesson planning and help them organize and use teaching-learning process effectively (Sahin-Taskin, 2017). To provide quality education in classrooms, prospective teachers need to gain adequate knowledge of new teaching strategies and activity based teaching through their learning at teacher training programs (Abidoudullah, Akbar, Akhtar \& Chaudhary, 2013).

Most of the participants consider formative assessment as their preferred assessment approach. Formative assessment seemed to be a central element in their teaching and learning. Research studies (Black \& Wiliam, 2009; Rivai, Ridwan, Supriyati, \& Rahmawati, 2019) also indicated that formative assessment methods have been important tools to raise overall levels of student achievement. Karim (2015), Karimi and Shafiee (2014), Kuze and Shumba (2011), Leung and Scott (2009) believe that, the 
way teachers carry out a formative assessment is strongly influenced by their beliefs. Those who have a high belief of formative assessment benefits are more likely to carry out formative assessment properly. However, the practices and implementation of formative assessment strategies is not always consistent with teachers' beliefs (Yahiji, Otaya, \& Anwar, 2019) as observed in this study. Sometimes, teachers did not intensively do what they believe. Therefore, to make assessment more effective, teachers need further training.

Feedback emerged as an important theme in this study. Many participants talked about importance of giving feedback. Research insists on constructive feedback that helps students to improve their learning. For instance, Black and Wiliam (2009) stated that, feedback should cover particular qualities of students' work, with advice about what they can do to improve and should avoid comparisons with others. In order to make feedback useful for students, it should be given timely, goal oriented, task oriented and precise. Purpose of feedback must be to inform students about the ways by which they can foster their learning (Ahmed, Islam \& Salahuddin, 2015; Rahman \& Ahmed, 2010). As seen in the assignments, instead of highlighting students' strengths and areas of improvement, most of the teachers had just underlines and tick/ cross. Participants' beliefs regarding feedback were inconsistent with their practices. Yasmin (2012) found that teachers have emphasized on grades and marks as practice of feedback. They included making comments using 'good', 'very good', putting 'cross/tick mark' on the answers. Right-wrong answer feedback focuses on product of students learning rather than learning process. Sadler (2013) has rightly highlighted that like grades and marks, right-wrong answer feedback switches students' concentration 'how good I am'.

\section{RECOMMENDATIONS}

On the basis of findings and results, the researchers made following recommendations along with the practical implications for future studies.

- Participants' variation in their experience, qualifications, expertise, and skills in instructions may impact the beliefs and practices. Future studies can be carried out to investigate whether age, gender, academic qualification and teaching experience influence teachers' beliefs and practices or not.

- For effective classroom teaching and learning, university should emphasize more on formative assessment strategies so that teachers may use formative assessment in an appropriate way.

- University leadership and management need to take necessary steps to help teachers understand feedback mechanism with its full essence to ensure timely and constructive feedback mechanism in teaching and learning processes.

- Scope of the study might also be enhanced by investigating additional aspects of teachers' beliefs and practices that may provide different results.

- Further study is needed to broaden our understanding of the relationship between beliefs and change in practices and impact of teacher preparation programs.

\section{CONCLUSION}

The present study aimed to explore pedagogical believes and practices of teacher educators teaching in B.Ed. Hons. Elementary program at a local public sector university in Gilgit city. Sample included 10 teacher educators, selected through convenient sampling techniques. Findings revealed teacher educators' preferred teaching strategies along with importance of lesson planning and feedback mechanism in teaching and learning processes. Apart from this, findings revealed the influence of teacher preparation programs on teaching, learning and assessment and participants preferred approaches of assessment. In general, the results showed variety in pedagogical beliefs of teachers, especially those relating to feedback, assessment and teaching strategies. By considering that all teachers are professionally trained and experienced, it was expected that there would not be any differences in their beliefs and practices. However, variations were found in the areas of assessment and preferred teaching approaches. Thus, it is absolutely imperative that teachers should be given opportunities through in -service training and 
Teaching Beliefs and Practices of Teacher-Educators...

professional development programs to update their knowledge and skills. This attempt will help in translating teachers' beliefs into successful practices and implementation.

\section{REFERENCES}

Ahmed, S. S., Islam, M. S., \& Salahuddin, M. (2015). Classroom Assessment Practices in Urban Secondary Science Classes in Bangladesh. NAEM Journal, 10(19), 32-42.

Akbar, R. A., \& Akhtar, M. (2013). Beliefs and Practices of Teacher Educators Teaching B. Ed (Hons) and ADE in Universities and Affiliated Colleges in Punjab. Bulletin of Education and Research, 35(2), 91-106.

Black, P., \& William, D. (2009). Developing the Theory of Formative Assessment. Educational Assessment, Evaluation and Accountability, 21, 5-31.

Borg, S. (2003). Teacher cognition in language teaching; A review of research on what language teachers think, know, believe and do. Language Teaching, 36(2), 81-109.

Cohen, L., Manion, L., \& Morrison, K. (2007). Research Methods in Education (6th ed.). NY Routledge Falmer.

Corbin, J., \& Strauss, A. (2008). Basics of Qualitative Research: Techniques and Procedures for Developing Grounded Theory ( $3^{\text {rd }}$ ed.). Thousand Oaks, CA: Sage.

Darling-Hammond, L., \& Hudson, L. (1990). Precollege Science and Mathematics Teachers: Supply, Demand, \& Quality. Review of Research in Education, 16, 223-266.

Dilshad, M., \& Iqbal, H. M. (2010). Quality Indicators in Teacher Education Programmes. Pakistan Journal of Social Sciences (PJSS), 30(2), 401-411

Farrell, T. S. C., \& Bennis, K. (2013). Reflecting on ESL teacher beliefs and classroom practices: A case study. RELC Journal, 44(2), 163-176.

Feyfant, P.A. (2011). The Effects of Pedagogical Practices on Learning. Current Literature Review in Education, 80, 1-18.

Fredricks, J. A., Blumenfeld, P. C., \& Paris, A. H. (2004). School engagement: Potential of the concept, state of the evidence. Review of Educational Research, 74(1), 59-109.

Gabryś-Barker D. (2010). Conceptualizing classroom space, In Ciuk A., Molek-Kozakowska K. (eds.), Exploring space: Spatial notions in cultural, literary and language studies. Space in Language Studies. Newcastle-upon-Tyne: Cambridge Scholars Publishing.

Gall, M., Borg, W., \& Gall, J. (2003). Educational Research: An Introduction (7 $7^{\text {th }}$ ed.). Pearson.

Government of Pakistan. (2009). National Professional Standards for Teachers in Pakistan, Policy and Planning Wing, Ministry of Education, Government of Pakistan, Islamabad Pakistan.

Guerra, P.L., \& Wubbena, Z.C. (2017). Teacher Beliefs and Classroom Practices Cognitive Dissonance in High Stakes Test-Influenced Environments. Issues in Teacher Education, 26(1), 35-51.

Hurst, B. (2001). ABCs of content area lesson planning: Attention, basics, and comprehension. Journal of Adolescent \& Adult Literacy, 44(8), 692-693.

Johnson, D. W., Johnson R.T., \& Smith K. A. (1998). Active Learning: Cooperation in the College Classroom, Interaction Book Co., Edina, MN.

Karim, B. H. H. (2015). The impact of teachers' beliefs and perceptions about formative assessment in the university ESL class. International Journal of Humanities, Social Sciences and Education, 2(3), 108-115.

Karimi, M. N., \& Shafiee, Z. (2014). Iranian EFL teachers' perceptions of dynamic assessment: Exploring the role of education and length of service. Australian Journal of Teacher Education, 39(8), 143-162.

Khader, F. R. (2012). Teachers' Pedagogical Beliefs and Actual Classroom Practices in Social Studies Instruction. American International Journal of Contemporary Research, 2(1), 73-92.

Khan, S. H., \& Saeed, M. (2009). Effectiveness of Pre-service Teacher Education Programme (B. Ed) in Pakistan: Perceptions of Graduates and their Supervisors'. Bulletin of Education and Research, 31(1), 83-98. 
Ko, E. K. (2012). What is your objective? Preservice teachers' views and practice of instructional planning. The International Journal of Learning, 18(7), 89-100.

Kuze, M. W., \& Shumba, A. (2011). An Investigation into formative assessment practices of teachers in selected schools in fort Beauport in South Africa. Journal of Social Sciences, 29(2), 159-170.

Leung, C., \& Scott, C. (2009). Formative assessment in language education policies: Emerging lessons from Wales and Scotland. Annual Review of Applied Linguistics, 29, 64-79.

Li, L. \& Walsh, S. (2011). Seeing is believing': Looking at EFL Teachers' Beliefs through Classroom Interaction. Classroom Discourse, 2(1), 39-57.

Merriam, S. (2009). Qualitative research: A guide to design implementation. San Francisco, CA: Jossey Bass.

Munshi, D. P., Parveen, D. S., Bhatti, D. T., Mirza, M. N., \& Chachar, M. Z. A. (2015). The Teaching Practices of Teacher Educators in ADE/B. Ed.(Hons) Elementary Programs in Sindh: An Evaluative Study. The Sindh University Journal of Education-SUJE, 44(2),31-39.

Ng, E. K. J., \& Farrell, T.S.C. (2003). Do Teachers' Beliefs of Grammar Teaching Match their Classroom Practices? A Singapore Case Study. In D. Deterding. Brown A \& Low E L (Eds. 2003) English in Singapore: Research on Grammar. Singapore (pp. 128-137): McGraw Hill.

Purnomo, Y. W., Suryadi, D., \& Darwish, S. (2017). Examining pre-service elementary school teacher beliefs and instructional practices in mathematics class. International Electronic Journal of Elementary Education, 8(4), 629-642.

Radhika, K. (2020). Pedagogical approaches in early childhood Education. International Journal of Professional Studies, 8, 1-11.

Rahman, M. M., \& Ahmed, S. S. (2010). Classroom Assessment and Student Learning: An Exploration of Secondary School Teacher Practices. NAEM Journal, 5(10), 32-44.

Rubin, K. H., Bukowski, W. M., \& Laursen, B. (Eds.). (2009). Handbook of peer interactions, relationships, and groups. The Guilford Press.

Rivai, E., Ridwan, A., Supriyati, Y., \& Rahmawati, Y. (2019). Influence of test construction knowledge, teaching material and attitude on sociological subject to quality of objective test in public and private vocational schools. International Journal of Instruction, 12(3), 497-512.

Sadler, D. R. (2013). Opening up feedback: Teaching learners to see. In Merry, S., Price, M., Carless, D., \& Taras, M. (Eds.). Re-conceptualizing Feedback in Higher Education: developing dialogue with students, (Ch. 5, 54-63). Routledge.

Sahin-Taskin, C. (2017). Exploring Pre-service Teachers' Perceptions of Lesson Planning in Primary Education. Journal of Education and Practice, 8(12), 57-63.

Saydee, F. (2015). Foreign language teaching: A study of teachers' beliefs about effective teaching and learning methodologies. NCOLCTL.18, 63-91.

Sturko, P., \& Holyoke, L. (2009). Evaluating professional development that prepares teachers to integrate academic skills into technical curricula. Professional Development in Education, 35(2), 211- 225.

Thomas, M. (2013). Teachers' Beliefs about Classroom Teaching — Teachers' Knowledge and Teaching Approaches. Procedia - Social and Behavioral Sciences, 89, 31- 39.

Wentzel, K. R. (2009). Peers and academic functioning at school. In K. H. Rubin, W. M. Bukowski, \& B. Laursen (Eds.), Handbook of peer interactions, relationships, and groups (pp. 531-547). The Guilford Press.

Yahiji, K., Otaya, L.G., \& Anwar, H. (2019). Assessment model of student field practice at faculty of tarbiyah and teaching training in Indonesia: A reality and expectation. International Journal of Instruction, 12(1), 251-268.

Yamashita, M. Y. (2011). How does high stakes testing influence teachers' classroom instruction? Institutional pressures and classroom instruction. [Doctoral dissertation, University of Pittsburgh, Pittsburgh, PA]

Yasmin, N. (2012). Exploring Secondary School Teachers' Attitude towards Classroom Assessment and its Implications for Students' Learning. Unpublished masters' thesis, Institute of Education and Research, University of Dhaka, Bangladesh. 
Yin, R. K. (2003). Case study research: Design and methods. Sage Publications.

Zohrabi, M. (2013). Mixed Method Research: Instruments, Validity, Reliability and Reporting Findings. Theory \& practice in language studies, 3(2), 254-262.

8 Ways Open Pedagogy Benefits Teachers and Learners. (2018). Retrieved from myboardshare.com

APPENDIX A

Demographic data for the individual participants

\begin{tabular}{lll}
\hline Demographics & $\mathbf{n = 1 0}$ & Percentage breakdown \\
\hline Type of teacher & 5 & $50 \%$ \\
Regular faculty & 5 & $50 \%$ \\
Visiting faculty & & \\
& & \\
Gender & 4 & $40 \%$ \\
Male & 6 & $60 \%$ \\
Female & & \\
Academic qualification & & \\
PhD & 4 & $40 \%$ \\
M.Phil & 6 & $60 \%$ \\
& & \\
Years teaching experience & & \\
More than 5 years & & \\
4-5 years & 4 & $30 \%$ \\
2-3 years & 3 & \\
\hline
\end{tabular}

\section{APPENDIX B}

Preferred teaching strategies by participants

\begin{tabular}{ll}
\hline Strategies & No of references \\
\hline Cooperative learning & 9 \\
Group work/group activities & 10 \\
ICT integration & 3 \\
Think pair share & 2 \\
Discussions & 9 \\
Presentations & 10 \\
Lecture method & 8 \\
Role play & 2 \\
Games & 1 \\
Jigsaw & 1 \\
Say and switch & 1 \\
\hline
\end{tabular}




\begin{tabular}{ll} 
APPENDIX C \\
List and frequencies of different assessment approaches used by teachers to assess their students. \\
\hline assessment types/approaches & Number of occurrence \\
\hline Quizzes and exams & 5 \\
Presentations & 8 \\
Self-reflective exercises & 2 \\
assignments & 10 \\
Assessing group work & 7 \\
concept maps & 2 \\
rubrics & 3 \\
\hline
\end{tabular}

